\title{
Investors Perception towards Investments in Derivatives
}

\begin{abstract}
The most significant aspect of derivatives is risk management not about the elimination of risk. For Conducting ordinary mode of business operations financial derivatives affords a powerful tool for limiting risks to the investors. There are various derivative instruments like index futures. Stock futures, index option, stock options, interest rate futures, currency option, currently traded in these exchanges. The derivative investors ought to perceive the market trend, market reforms, government policies, market regulations; factors influencing derivatives investment [Motivating Factors], return, investment opportunities obviously and adequately take prudent investment decisions. The present study investigates the investors perception towards investments in the derivatives market at Hyderabad region. The data were collected through questionnaire survey from 322 respondents in Hyderabad region.
\end{abstract}

Key Words: Investors Perception, Derivative Instruments, Risk.

\section{INTRODUCTION}

Over the past decades Investing has become complicated as various types of derivative instruments have been created. Particularly in trading system at a specific date on a specific price, one party agrees to sell goods and another party agrees to buy goods in the market, use of derivatives has been around for a long period. In an organized market bartering of goods and services was accomplished via handshake.

"Derivative is a financial instrument whose value depends on (or derived from) the value of other, more basic underlying variables". Financial derivatives are the innovative risk management products and financial services. Essentially, it is a future contract which is made between two parties and its value is derived from the original financial asset which may be Equity, Bonds or Foreign Exchange etc., depending upon the nature of financial transactions. A variety of derivative contracts are introduced. Such as Forward Contracts, Future Contracts, Options, Swaps etc. Each financial derivative has its own unique features.

\section{A. Forward Contracts}

A forward contract is an agreement between parties to buy/sell a specified quantity of an asset at a certain price. In simple words, it is a simple customized contract between two parties to buy or sell an asset for a certain price at a certain time in future.

Revised Manuscript Received on October 30, 2019.

* Correspondence Author

Dr. N Renuka*, Professor in Avanthi PG College, Dilsukhnagar, Hyderabad, Telangana State, India.

(c) The Authors. Published by Blue Eyes Intelligence Engineering and Sciences Publication (BEIESP). This is an open access article under the CC-BY-NC-ND license http://creativecommons.org/licenses/by-nc-nd/4.0/

A forward contract is custom designed, and hence, it is unique in terms of contract size, maturity date, quality and quantity of asset, etc. The contract is settled by the delivery of asset on the expiration date. Forward contracts being bilateral contracts are exposed to counter party risk.

\section{B. Future Contracts}

Future Contacts are special type of forward contracts. Many features of "Futures" are similar to forward contracts. A 'future contract' differs from a forward contract in that the 'future contract' is a standardised contract written by a clearing house that operates an exchange where the underlying can be bought and sold. In a simple language, a futures contract is transacted through in exchange.

\section{Option Contracts}

"An Option is an instrument or contract that gives the holder a right, without any obligation, to buy or sell specified quantity of the underlying assets at an agreed price on or before a specified future date".

Types of Option: Call Option and Put Option.

\section{Swaps}

Swap or Swop means barter or exchange. "A swap is an agreement between two parties to exchange sequence of cash flows over a period in the future".

Types of Swaps: There are five basic types of swaps.

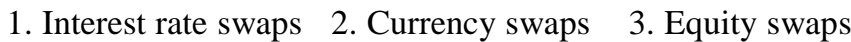

4. Credit swaps 5. Commodity swaps

\section{STATEMENT OF THE PROBLEM}

Derivatives are new segment of secondary market operation in India; investors need to understand trade process and to make profit in derivatives market. Importance of investor has become increasing order because of Technological advancements in trading system, rapid growth of derivative market and new economic policy of 1991. Behaviour of investors tends to moves from savings to investment. Because of liberalized regulation in the capital market, a large number of brokers have been entered into the capital market, based on the requirement of the investor, brokers provides huge amount of services under single umbrella. Theoretically, the impact of stock index futures and options on the stock market volatility is still not clear. In generally the relationship between derivatives markets activities and the stock market activities is recognized through arbitraging activities. After the introduction of derivative products, the spot market and future markets are linked through hedging of funds which may cause to increasing in volatility of the component stocks. 
Growth in financial derivatives market and reports of major losses from derivative products which is creates a great deal of confusion about derivative instruments. Based on the above issues, the following questions are investigated:

1. What are the factors should be considered for investment in derivative market in India?

2. Investors Investment decisions in derivative market should be taken with complete knowledge or not?

This study has been conducted to assess the investors' perception towards derivative market in India through addressing solutions to the above mentioned pertinent questions.

\section{OBJECTIVES OF THE STUDY}

1. To study the Socio - Economic profile of the investors in derivative market in India.

2. To study the investors investment preference reasons for the investments in derivative market in India.

3. To study the impact of the investors investment decisions on preferences of the derivative market in India.

4. To analyze the investors investment decision on derivative market in India.

\section{HYPOTHESIS OF THE STUDY}

1. There is no significant association between Socio Economic variables and investments in derivative market in India.

2. There is no significant association between the investors behaviour variables and investment preferences in derivative market in India.

\section{REVIEW OF LITERATURE}

Szyszka Adam (2008), "Behavioural Anatomy of the Financial Crisis". The study analyzed psychology of the investors and how the investor changes the vision of the financial markets. In his study, investors are not able to value the utility of the decision alternatives and improper diversification of funds will takes place.

Fauver and Naranjo (2010), "Derivative Usage and Firm Value: The Influence of Agency Costs and monitoring Problems". The study concludes firms which is effectively use the derivative instruments generates wealth to the shareholders, magnifies the endogeneity in the value of the firm and hedging researches and direct impact on firm value. Korniotis and Kumar (2011) suggested older people make better investment choices and the conception of risk tolerance is highly important for investors' asset allocations. He determines the determinants of risk tolerance are important factor in behavioural finance.

Allayannis, Lel and Miller (2012)," Use of Foreign Currency Derivatives and Firm Market Value". The study explores that the impact of expectations of investors returns and risk tolerance is positive and

impact of investors perception towards risk is negative.

Tripathi (2014), “An Empirical Investigation of Investors' Perception towards Derivative Trading in India". The study explores most of the investors preferred to invest in real assets and insurance with the expectation of higher returns and it consists low risk.
Y. Nagaraju (2014), A Study on Investors' Perception Towards Derivative Instruments and Markets. The study concludes that before making of investment the investor should take effective measurements and determining the factors of risk for investment decision on particular financial instruments.

D.V.Gakhar (2016), "A Study of Impact on Volatility and Investor Perception" The study explores that the investors awareness and investors investment decisions and risk taking ability on derivative instruments plays an important role in the development of trading activities in derivative market.

Gopal Krishna U M (2019) "Investors Perception towards Investment Avenues". The study explores that the Investors investment behaviour and risk taking ability on various investment avenues.

Gopal Krishna U M (2019) "Perception of Investors towards risk in various Investment Avenues" The study concludes the ability of risk behind the particular financial instruments in capital market.

\section{RESEARCH METHODOLOGY}

The research design applied for this study is analytical and descriptive in nature. Both primary and secondary data were used in this study. The primary data was collected from investors of derivative market in Hyderabad region by adopting Convenience sampling method with a sample size of 322 respondents. The secondary data was collected in the form of reports published by derivatives market, stock market website in India, journals, magazines, periodicals and dailies. The statistical tools applied for this study is SPSS STATISTICS 21 \& SPSS AMOS 21 versions.

\section{LIMITATIONS OF THE STUDY}

1. The Study area s limited to Hyderabad region only.

2. Some respondents are not interested to disclose the personal investment details.

3. Some respondents are feel hesitated because of busy work schedules.

\section{DATA ANALYSIS AND INTERPRETATIONS}

Table: 1.1 Model Fit Summary:

\begin{tabular}{|c|c|c|c|c|}
\hline Model & $\mathbf{R}$ & $\begin{array}{c}\mathbf{R} \\
\text { Square }\end{array}$ & $\begin{array}{c}\text { Adjusted } \\
\text { R } \\
\text { Square } \\
\end{array}$ & $\begin{array}{l}\text { Std. } \\
\text { Error of } \\
\text { the } \\
\text { Estimate }\end{array}$ \\
\hline $\begin{array}{l}\text { Preference } \\
\text { in } \\
\text { Forward } \\
\text { Contract }\end{array}$ & 0.231 & 0.054 & 0.031 & 1.015 \\
\hline
\end{tabular}

The table 1.1 infers $R, R^{2}$, adjusted $R^{2}$, Standard error of the estimate and model fits. Multiple Correlation coefficients 0.231 is Average predication level. Among all the variables like Risk, Return, Safety, Tax Benefits and Future Needs variables are $54 \%$ of respondents are dependent in Preference reasons on Forward Contract. 


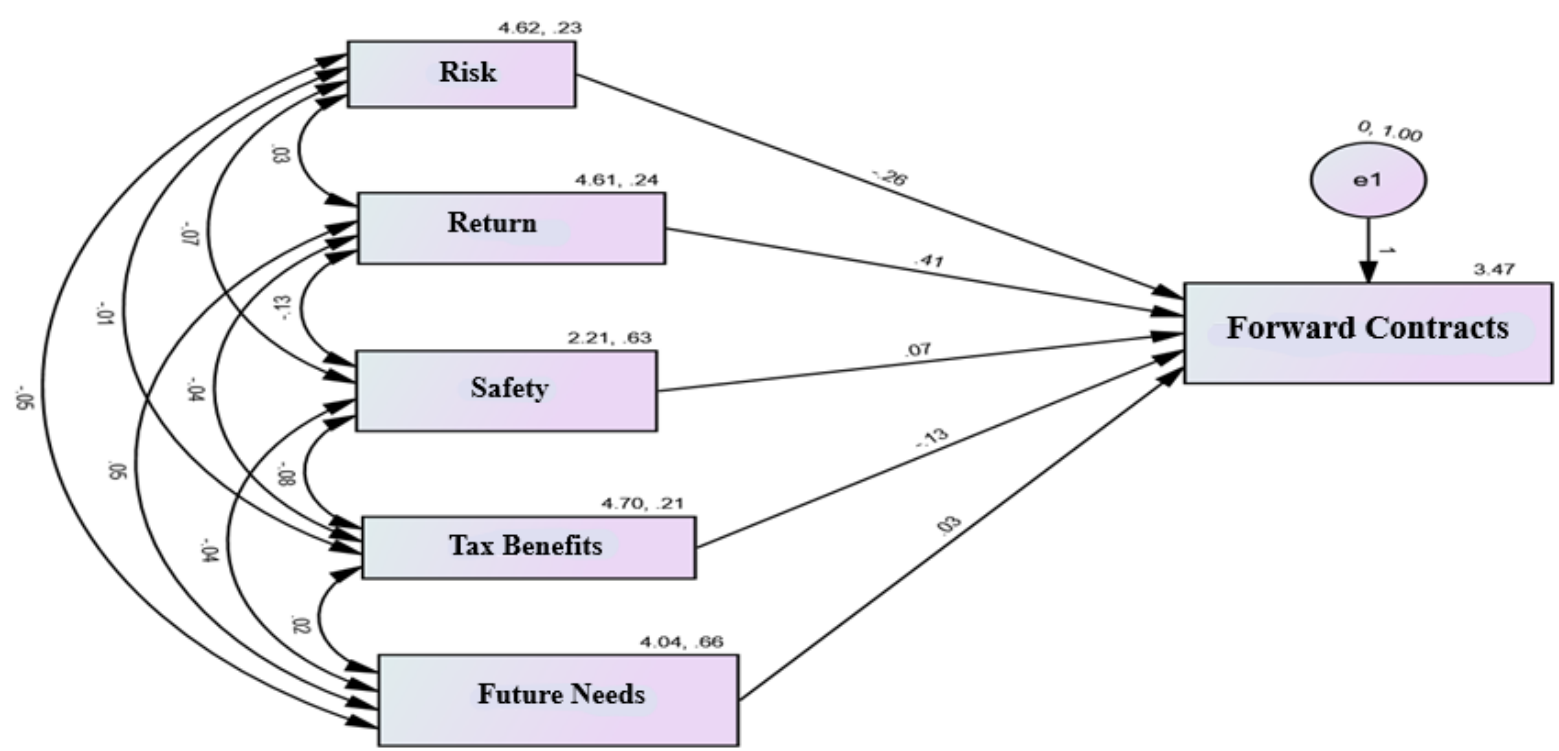

Figure 1.1 Multiple Regression Path Analysis of Investors Preference Reason in Forward Contract Investments

Table 1.2 Regression Weights of Investors Preference reasons in Forward Contract Investments:

\begin{tabular}{|l|r|r|r|c|}
\hline \multicolumn{1}{|c|}{$\begin{array}{c}\text { Regression } \\
\text { Weights }\end{array}$} & Estimate & S.E. & C.R. & P \\
\hline $\begin{array}{l}\text { Forward } \\
\text { Contracts <--- } \\
>\text { Risk }\end{array}$ & -0.264 & 0.145 & 1.826 & 0.068 \\
\hline $\begin{array}{l}\text { Forward } \\
\text { Contracts <--- } \\
>\text { Return }\end{array}$ & 0.409 & 0.153 & 2.663 & 0.008 \\
\hline $\begin{array}{l}\text { Forward } \\
\text { Contracts <--- } \\
>\text { Tax Benefits }\end{array}$ & 0.067 & 0.096 & 0.701 & 0.483 \\
\hline $\begin{array}{l}\text { Forward } \\
\text { Contracts <--- } \\
>\text { Safety }\end{array}$ & -0.127 & 0.156 & 0.811 & 0.417 \\
\hline $\begin{array}{l}\text { Forward } \\
\text { Contracts <--- } \\
>\text { Future } \\
\text { Needs }\end{array}$ & & & & \\
\hline
\end{tabular}

The above figure 1.1 indicates that the Forward Contracts investment preference reasons and applied multiple regression analysis; there is significant relationship with Forward Contracts Investment Avenue with variable return. The regression weight is 0.409 . The squared multiple correlation estimates is 0.054 .

The analysis concludes investors highest preference reason in the Forward Contract investment is Returns.

Table 1.3 Correlation Matrix of the Investors Preference reasons in Forward Contract Investments:

\begin{tabular}{|c|c|c|c|c|c|c|}
\hline $\begin{array}{c}\text { Correlat } \\
\text { ion } \\
\text { Matrix }\end{array}$ & Risk & $\begin{array}{c}\text { Retur } \\
\mathbf{n}\end{array}$ & $\begin{array}{c}\text { Safet } \\
\mathbf{y}\end{array}$ & $\begin{array}{c}\text { Tax } \\
\text { Bene } \\
\text { fits }\end{array}$ & $\begin{array}{c}\text { Fut } \\
\text { ure } \\
\text { Nee } \\
\text { ds }\end{array}$ & $\begin{array}{c}\text { Prefere } \\
\text { nce in } \\
\text { Forwar } \\
\text { d } \\
\text { Contra } \\
\text { ct } \\
\end{array}$ \\
\hline $\begin{array}{l}\text { Risk } \\
\text { Return or } \\
\text { Income } \\
\text { Safety }\end{array}$ & $\begin{array}{r}1 \\
0.134 \\
-0.185\end{array}$ & -0.332 & 1 & & & \\
\hline
\end{tabular}

\begin{tabular}{|l|r|r|r|r|r|r|}
\hline Tax & -0.067 & -0.16 & - & 1 & & \\
Benefits & & & 0.212 & & & \\
Future & -0.127 & 0.116 & - & 0.42 & 1 & \\
Needs & & & 0.061 & & & \\
Preferenc & -0.107 & 0.171 & 0.021 & - & - & 1 \\
e in & & & & 0.089 & 0.12 & \\
Shares & & & & & 7 & \\
\hline
\end{tabular}

The above table1.3 shows correlation matrix of all the variables. From the analysis it concludes variables risk and return is highly correlated among variables. The correlate value is 0.314 ; the second higher correlate value is 0.116 , Future Needs and Return.

The next correlation ship variables are future needs and Tax benefits. The other variables correlated negatively. In Forward Contract investment preferences variables Return and Safety are highly correlated as $0.171 \& 0.021$.

Table 1.4 Covariance of Investors Preference reasons in Share Market Investment Avenue:

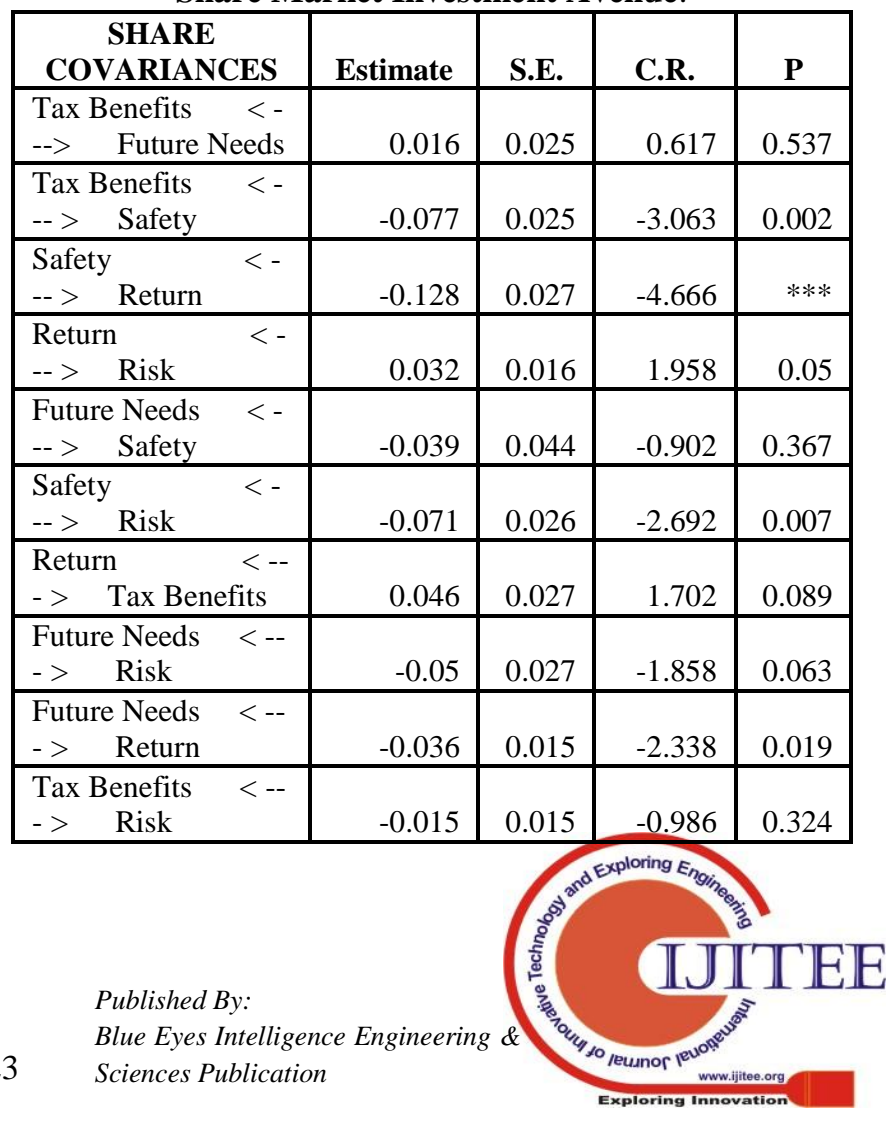


The above table1.4 interprets Covariance relationship of investors preference reason in Forward Contract Investment. There is significant relationship only on Return and Risk, the covariance estimate values are 0.32 respectively. There is significant relationship among Tax Benefits and Future Needs; Future Needs and Returns but P - Values of these variables are greater than 0.005 . Remaining relationship is significant from one another. The result concluded that Forward Contract Investors Preference reasons are like Return and Risk which is highly interrelationship, the covariance estimate values are 0.32 respectively.
Table: 2.1 Model Fit Summary

\begin{tabular}{|c|c|c|c|c|}
\hline Model & $\mathbf{R}$ & $\begin{array}{c}\text { R } \\
\text { Square }\end{array}$ & $\begin{array}{c}\text { Adjusted } \\
\text { R } \\
\text { Square }\end{array}$ & $\begin{array}{c}\text { Std. } \\
\text { Error of } \\
\text { the } \\
\text { Estimate }\end{array}$ \\
\hline $\begin{array}{l}\text { Preference } \\
\text { in Futures } \\
\text { Contract }\end{array}$ & 0.366 & 0.134 & 0.114 & 0.7547 \\
\hline
\end{tabular}

The table 2.1 infers $R, R^{2}$, adjusted $R^{2}$, Standard error of the estimate and model fits. Multiple Correlation coefficients 0.366 is good level of predication.. Among all the variables like Risk, Return, Safety, Tax Benefits and Future Needs variables are $95 \%$ of respondents are dependent in Preference reasons on Futures market.

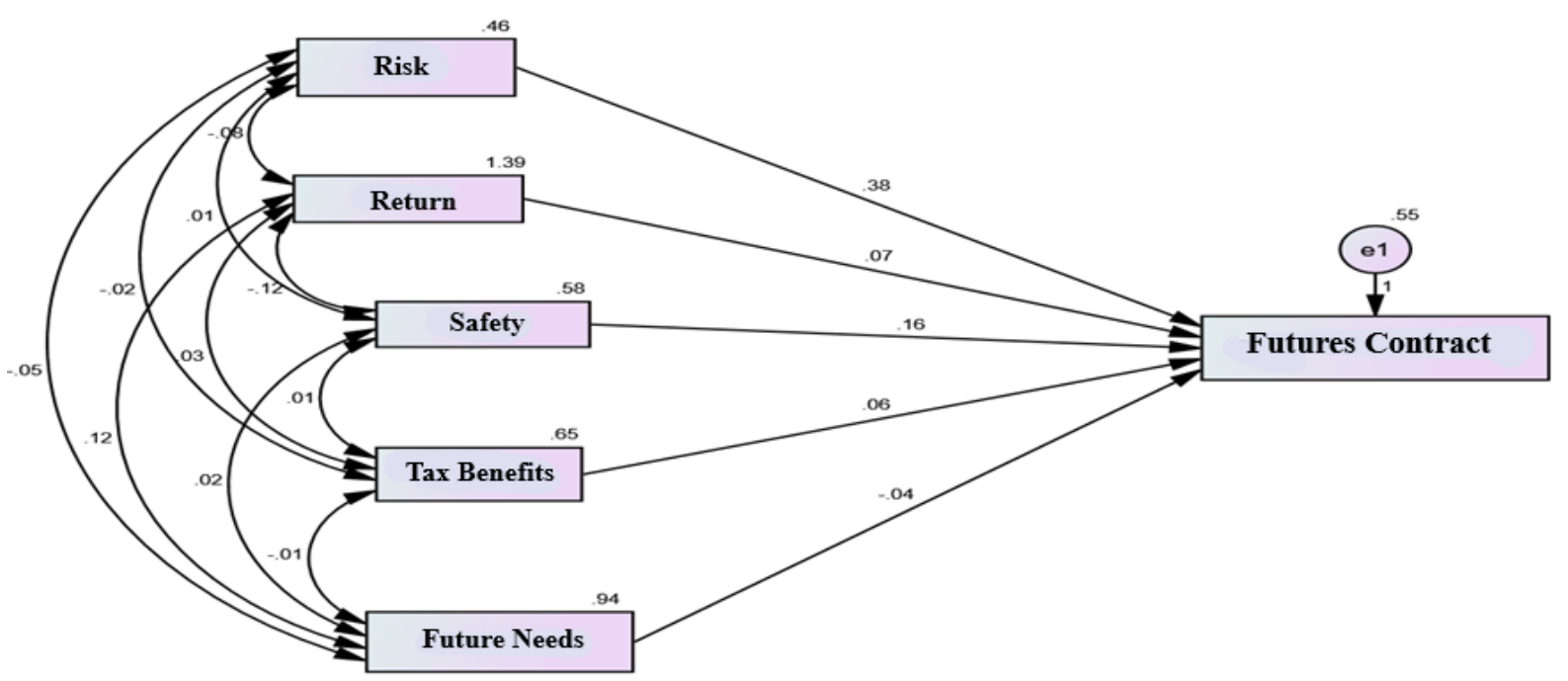

Figure2:1 Multiple Regression Path Analysis of Investors Preference Reason in Future Contract Investment:

Table: 2.2 Regression Weights of Investors Preference reasons in Future Contract Investments:

\begin{tabular}{|l|r|r|r|r|}
\hline $\begin{array}{l}\text { Regression } \\
\text { Weights }\end{array}$ & Estimate & S.E. & C.R. & P \\
\hline $\begin{array}{l}\text { Preference } \\
\text { Shares <--- } \\
>\text { Risk }\end{array}$ & 0.377 & 0.074 & 5.065 & $* * *$ \\
\hline $\begin{array}{l}\text { Preference } \\
\text { Shares <--- } \\
>\text { Return }\end{array}$ & 0.072 & 0.043 & 1.664 & 0.096 \\
\hline $\begin{array}{l}\text { Preference } \\
\text { Shares <--- } \\
>\text { Tax } \\
\text { Benefits }\end{array}$ & 0.161 & 0.067 & 2.419 & 0.016 \\
\hline $\begin{array}{l}\text { Preference } \\
\text { Shares <-- } \\
>\text { Safety }\end{array}$ & 0.061 & 0.063 & 0.975 & 0.329 \\
\hline $\begin{array}{l}\text { Preference } \\
\text { Shares <--- } \\
>\text { Future } \\
\text { Needs }\end{array}$ & -0.038 & 0.052 & -0.734 & 0.463 \\
\hline
\end{tabular}

The above figure 2.1 indicates that the Futures Contracts investment preference reasons and applied multiple regression analysis; there is significant relationship with Forward Contracts Investment Avenue with variable return. The regression weight is 0.072 . The squared multiple correlation estimates is 0.754 .
The analysis concludes investor first and foremost leading preference reason in the Futures Contract investment is Risk and its estimated value is 0.377 and next preference reason is Safety and their estimated value is 0.16.

Table: 2.3 Correlation Matrix of the Investors Preference reasons in Future Contract Investment Avenue:

\begin{tabular}{|l|r|r|r|r|r|r|}
\hline $\begin{array}{l}\text { Corre } \\
\text { lation } \\
\text { Matri } \\
\mathbf{x}\end{array}$ & Risk & $\begin{array}{r}\text { Retur } \\
\text { n }\end{array}$ & $\begin{array}{r}\text { Safe } \\
\text { ty }\end{array}$ & $\begin{array}{c}\text { Tax } \\
\text { Bene } \\
\text { fits }\end{array}$ & $\begin{array}{c}\text { Futu } \\
\text { re } \\
\text { Need } \\
\text { s }\end{array}$ & $\begin{array}{c}\text { Prefere } \\
\text { nce in } \\
\text { Futures } \\
\text { Contrac } \\
\text { ts }\end{array}$ \\
\hline Risk & 1 & & & & & \\
\hline Return & -0.105 & 1 & & & & \\
\hline Safety & 0.011 & -0.13 & 1 & & & \\
\hline $\begin{array}{l}\text { Tax } \\
\text { Benefi } \\
\text { ts }\end{array}$ & -0.027 & 0.035 & 0.00 & 1 & & \\
\hline $\begin{array}{l}\text { Future } \\
\text { Needs }\end{array}$ & -0.076 & 0.103 & 0.03 & 0.00 & 1 & \\
\hline $\begin{array}{l}\text { Prefer } \\
\text { ence } \\
\text { in }\end{array}$ & 0.313 & 0.05 & 0.14 & - & - & \\
$\begin{array}{l}\text { Future } \\
\text { Contra } \\
\text { cts }\end{array}$ & & & 2 & 0.05 & 0.056 & \\
\hline
\end{tabular}


The above table 2.3 shows correlation matrix of all the variables. From the analysis it concludes variables future needs and return is highly correlated among the variables. The correlate value is 0.103 ; the second higher correlate value is 0.035 , Tax benefits and Return. The next correlation ship variables are future needs and safety. The other variables correlated negatively. In Future Contract investment preferences variables Risk, Return, Safety and Tax Benefits are highly correlated with values of 0.313 , $0.050,0.142$, and 0.058 .

Table: 2.4 Covariance of Investors Preference reasons in Futures Contract Investment Avenue:

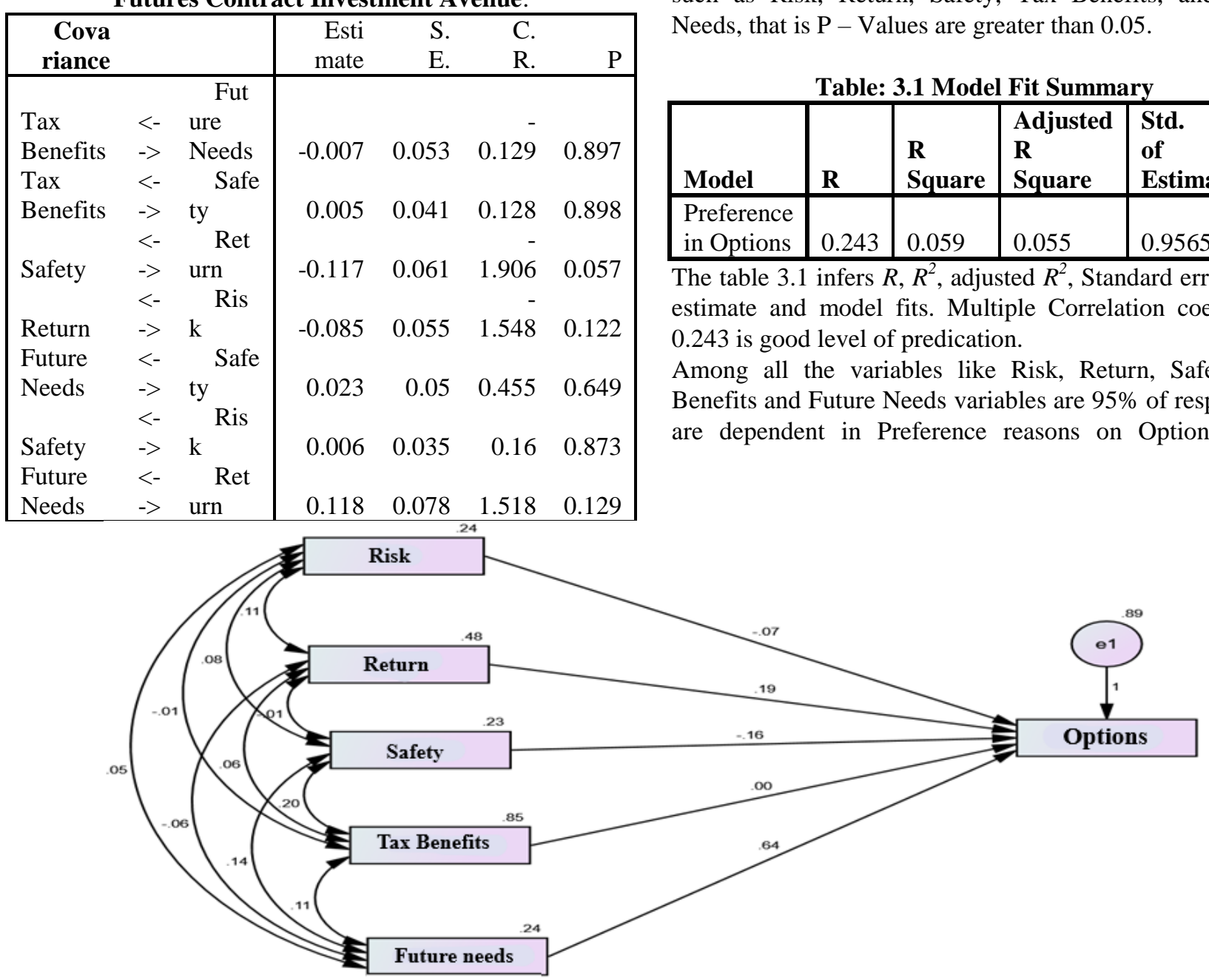

Figure: 3.1 Multiple Regression Path Analysis of Investors Preference Reason in Options Investment

Table: 3.2 Regression Weights of Investors Preference reasons in Share Market Investment Avenue:

\begin{tabular}{|l|l|l|l|l|}
\hline $\begin{array}{l}\text { Regression } \\
\text { Weights }\end{array}$ & Estimate & S.E. & C.R. & P \\
\hline $\begin{array}{l}\text { Options <-- } \\
->\text { Risk }\end{array}$ & -0.068 & 0.152 & -0.449 & 0.654 \\
\hline $\begin{array}{l}\text { Options <-- } \\
->\text { Return }\end{array}$ & 0.192 & 0.103 & 1.871 & 0.061 \\
\hline $\begin{array}{l}\text { Options <-- } \\
->\quad \text { Tax } \\
\text { Benefits }\end{array}$ & -0.16 & 0.184 & -0.872 & 0.383 \\
\hline $\begin{array}{l}\text { Options <-- } \\
->\text { Safety }\end{array}$ & 0.004 & 0.08 & 0.054 & 0.957 \\
\hline $\begin{array}{l}\text { Options <- } \\
-->\text { Future } \\
\text { Needs }\end{array}$ & 0.641 & 0.164 & 3.908 & $* * *$ \\
\hline
\end{tabular}

\begin{tabular}{|c|c|c|c|c|c|c|}
\hline Future & $<-$ & Ris & & & - & \\
\hline Needs & $->$ & $\mathrm{k}$ & -0.05 & 0.045 & 1.116 & 0.264 \\
\hline Tax & $<-$ & Ret & & & & \\
\hline Benefits & $->$ & urn & 0.034 & 0.064 & 0.524 & 0.6 \\
\hline Tax & $<-$ & Ris & & & - & \\
\hline Benefits & $->$ & $\mathrm{k}$ & -0.015 & 0.037 & 0.406 & 0.685 \\
\hline
\end{tabular}

The above table 2.4 interprets Covariance relationship of investors preference reason in Futures Contract Investment. The multiple regression path analysis results concludes, There is no significant relation between any of the variables such as Risk, Return, Safety, Tax Benefits, and Future Needs, that is $\mathrm{P}-$ Values are greater than 0.05 .

Table: 3.1 Model Fit Summary

\begin{tabular}{|c|c|c|c|c|}
\hline Model & $\mathbf{R}$ & $\begin{array}{l}\mathbf{R} \\
\text { Square }\end{array}$ & $\begin{array}{l}\text { Adjusted } \\
\mathbf{R} \\
\text { Square } \\
\end{array}$ & $\begin{array}{lr}\text { Std. Error } \\
\text { of } \\
\text { Estimate }\end{array}$ \\
\hline $\begin{array}{l}\text { Preference } \\
\text { in Options }\end{array}$ & 0.243 & 0.059 & 0.055 & 0.9565 \\
\hline
\end{tabular}

The table 3.1 infers $R, R^{2}$, adjusted $R^{2}$, Standard error of the estimate and model fits. Multiple Correlation coefficients 0.243 is good level of predication.

Safety, Tax Benefits and Future Needs variables are $95 \%$ of respondents are dependent in Preference reasons on Optionsmarket.
The above figure 3.1 indicates that the Option Contracts investment preference reasons and applied multiple regression analysis; there is significant relationship with Option Contracts Investment Avenue with variable Future Needs. The regression weight is 0.641 . The squared multiple correlation estimates is 0.059 .

The analysis concludes investors highest preference reason in the Forward Contract investment is Future Needs 
Table: 3.3 Correlation Matrix of the Investors Preference reasons in Options Market Investment:

\begin{tabular}{|c|c|c|c|c|c|c|}
\hline $\begin{array}{l}\text { Correlati } \\
\text { on } \\
\text { Matrix }\end{array}$ & Risk & $\begin{array}{l}\text { Retur } \\
\text { n }\end{array}$ & $\begin{array}{l}\text { Safe } \\
\text { ty }\end{array}$ & $\begin{array}{l}\text { Tax } \\
\text { Benefit } \\
\text { s }\end{array}$ & $\begin{array}{l}\text { Futu } \\
\text { re } \\
\text { Nee } \\
\text { ds }\end{array}$ & $\begin{array}{l}\text { Pref } \\
\text { eren } \\
\text { ce } \\
\text { in } \\
\text { Opti } \\
\text { ons }\end{array}$ \\
\hline Risk & 1 & & & & & \\
\hline $\begin{array}{l}\text { Return or } \\
\text { Income }\end{array}$ & 0.317 & 1 & & & & \\
\hline Safety & 0.33 & -0.033 & 1 & & & \\
\hline $\begin{array}{l}\text { Tax } \\
\text { Benefits }\end{array}$ & -0.012 & 0.087 & $\begin{array}{l}0.43 \\
8\end{array}$ & 1 & & \\
\hline $\begin{array}{l}\text { Future } \\
\text { Needs }\end{array}$ & 0.221 & -0.176 & $\begin{array}{l}0.57 \\
7 \\
\end{array}$ & 0.238 & 1 & \\
\hline $\begin{array}{l}\text { Preferenc } \\
\mathrm{e} \quad \text { in } \\
\text { options }\end{array}$ & 0.053 & 0.071 & $\begin{array}{l}0.09 \\
1\end{array}$ & 0.057 & $\begin{array}{l}0.24 \\
3\end{array}$ & 1 \\
\hline
\end{tabular}

The above table 3.3 shows correlation matrix of all the variables. From the analysis it concludes variables safety and future needs is correlated highly among the variables. The correlate value is 0.577 ; the second higher correlate value is 0.438 , Tax benefits and Safety. The next correlation ship variables are Safety and Return; Return and Risk; Future needs and Tax benefits; Future needs and Risk; Tax Benefits and Return. The correlated values are 0.033, 0.317, $0.238,0.221$, and 0.087 . The other variables correlated negatively. In Options market investment preferences variables Future Needs \& Safety are highly correlated with values of $0.243 \& 0.991$ respectively.

Table: 3.4 Covariance of Investors Preference reasons in Options Market Investment Avenue:

\begin{tabular}{|lll|llll|}
\hline $\begin{array}{l}\text { COVAR } \\
\text { IANCES }\end{array}$ & & $\begin{array}{l}\text { Estim } \\
\text { ate }\end{array}$ & S.E. & C.R. & P \\
\hline $\begin{array}{l}\text { Tax } \\
\text { Benefits }\end{array}$ & $>$ & $\begin{array}{l}\text { Nuture } \\
\text { Needs }\end{array}$ & 0.107 & 0.031 & 3.426 & $* * *$ \\
& $<$ & $\begin{array}{l}\text { Tax } \\
\text { Benefi }\end{array}$ & & & & \\
Safety & $>$ & ts & 0.195 & 0.033 & 5.943 & $* * *$ \\
& $<--$ & & & & & \\
Return & $>$ & Safety & -0.011 & 0.023 & -0.486 & 0.627 \\
Risk & $>--$ & & & & & \\
& $>$ & Return & 0.107 & 0.024 & 4.469 & $* * *$ \\
\hline
\end{tabular}

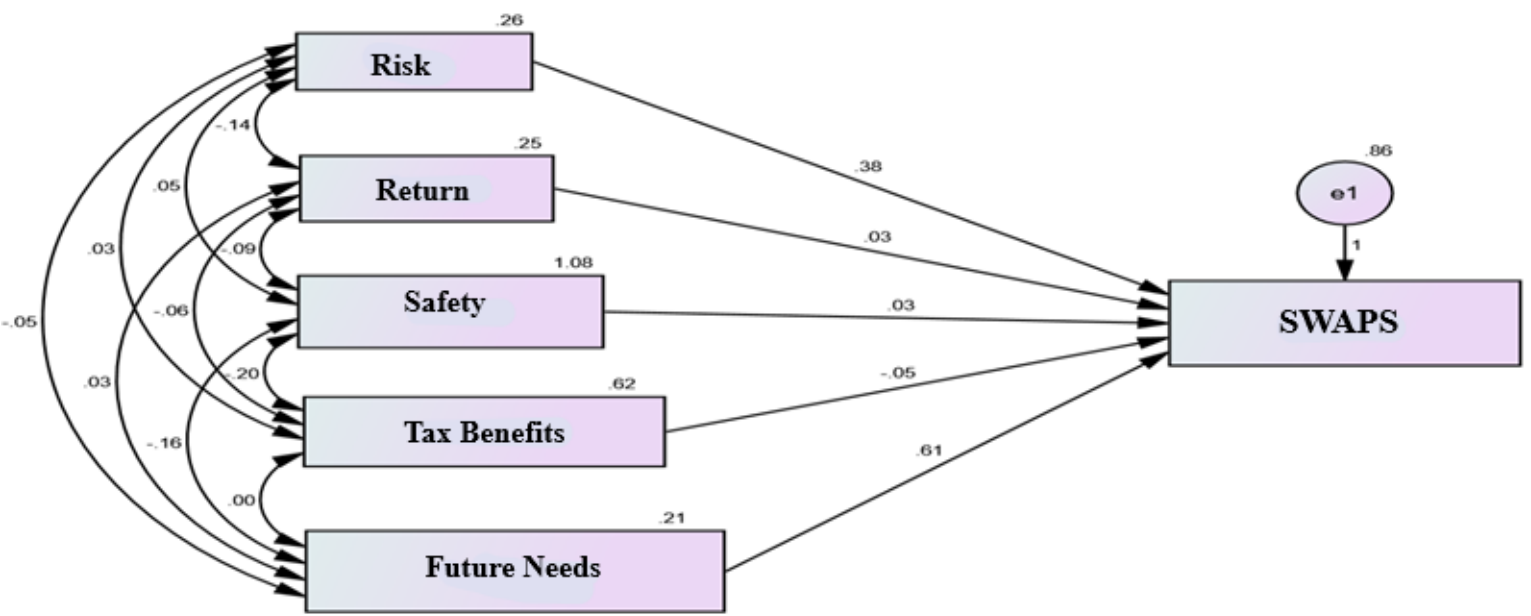

Figure: 4.2 Multiple Regression Path Analysis of Investors Preference reason in SWAPS Investments

\begin{tabular}{|c|c|c|c|c|c|c|}
\hline Safety & $\begin{array}{l}<-- \\
> \\
<--\end{array}$ & $\begin{array}{l}\text { Future } \\
\text { Needs }\end{array}$ & 0.136 & 0.018 & 7.395 & $* * *$ \\
\hline Risk & $\begin{array}{l}> \\
<--\end{array}$ & $\begin{array}{l}\text { Safety } \\
\text { Tax } \\
\text { Benefi }\end{array}$ & 0.078 & 0.017 & 4.638 & $* * *$ \\
\hline Return & $\begin{array}{l}> \\
<--\end{array}$ & $\begin{array}{l}\text { ts } \\
\text { Tax } \\
\text { Benefi }\end{array}$ & 0.056 & 0.043 & 1.289 & 0.197 \\
\hline Risk & $>$ & ts & -0.005 & 0.03 & -0.179 & 0.858 \\
\hline Return & $\begin{array}{l}<-- \\
>\end{array}$ & $\begin{array}{l}\text { Future } \\
\text { Needs }\end{array}$ & -0.059 & 0.023 & -2.568 & 0.01 \\
\hline Risk & $\begin{array}{l}<-- \\
>\end{array}$ & $\begin{array}{l}\text { Future } \\
\text { Needs }\end{array}$ & 0.053 & 0.017 & 3.188 & 0.001 \\
\hline
\end{tabular}

The above table 3.4 interprets Covariance relationship of investors preference reason in option Market Investment. There is significant relationship only on Tax Benefits and Future Needs; Safety and Tax Benefits; Risk and Return; Safety and Future Needs; Risk and Safety; Risk and Future Needs. The covariance estimate values are $0.107,0.136$, 0.078, and 0.053 respectively. There is significant relationship among Tax Benefits and Future Needs; Future Needs and Returns but $\mathrm{P}$ - Values of these variables are greater than 0.005 . Remaining relationship is significant from one another. The result concluded that Options Contract Investors Preference reasons are like Tax Benefits and Future Needs; Safety and Tax Benefits; Risk and Return; Safety and Future Needs; Risk and Safety; Risk and Future Needs which is highly interrelationship.

Table: 4.1 Model Fit Summary

\begin{tabular}{|l|c|c|c|c|}
\hline \multicolumn{1}{|c|}{ Model } & $\mathbf{R}$ & Square & $\begin{array}{c}\text { R } \\
\text { Square } \\
\mathbf{R}\end{array}$ & $\begin{array}{c}\text { Std. } \\
\text { Error of } \\
\text { the } \\
\text { Estimate }\end{array}$ \\
\hline $\begin{array}{l}\text { Preference } \\
\text { in } \\
\text { SWAPS }\end{array}$ & 0.299 & 0.09 & 0.081 & 0.9352 \\
\hline
\end{tabular}

The table 4.1 infers $R, R^{2}$, adjusted $R^{2}$, Standard error of the estimate and model fits. Multiple Correlation coefficients 0.299 is good level of predication. Among all the variables like Risk, Return, Safety, Tax Benefits and Future Needs variables are $90 \%$ of respondents are dependent in Preference reasons on Options market. 
Table: 4.2 Regression Weights of Investors Preference reasons in SWAPS Market Investment Avenue:

\begin{tabular}{|l|r|r|r|r|}
\hline $\begin{array}{l}\text { Regression } \\
\text { Weights }\end{array}$ & Estimate & S.E. & C.R. & P \\
\hline $\begin{array}{l}\text { SWAPS }<- \\
-->\text { Risk }\end{array}$ & 0.375 & 0.147 & 2.552 & 0.011 \\
\hline $\begin{array}{l}\text { SWAPS <- } \\
-->\text { Return }\end{array}$ & 0.035 & 0.154 & 0.225 & 0.822 \\
\hline $\begin{array}{l}\text { SWAPS <- } \\
-->\text { Tax } \\
\text { Benefits }\end{array}$ & 0.034 & 0.068 & 0.505 & 0.613 \\
\hline $\begin{array}{l}\text { SWAPS <- } \\
-->\text { Safety }\end{array}$ & -0.048 & 0.085 & -0.57 & 0.569 \\
\hline $\begin{array}{l}\text { SWAPS } \\
<--->\end{array}$ & & & & \\
$\begin{array}{l}\text { Future } \\
\text { Needs }\end{array}$ & 0.614 & 0.15 & 4.092 & $* * *$ \\
\hline
\end{tabular}

The above figure 4.1 indicates that the Swaps investment preference reasons and applied multiple regression analysis; there is significant relationship with Swaps investment Avenue with variable Future Needs. The regression weight is 0.614. The squared multiple correlation estimates is 0.935 .

The analysis concludes investors highest preference reason in the swaps investment is Future Needs.

Table: 4.3 Correlation Matrix of the Investors Preference reasons in SWAPS Market Investments:

\begin{tabular}{|c|c|c|c|c|c|c|}
\hline $\begin{array}{c}\text { Correlat } \\
\text { ion } \\
\text { Matrix } \\
\end{array}$ & $\begin{array}{c}\text { Ris } \\
\mathbf{k}\end{array}$ & $\begin{array}{c}\text { Retu } \\
\text { rn }\end{array}$ & $\begin{array}{c}\text { Safe } \\
\text { ty }\end{array}$ & $\begin{array}{l}\text { Tax } \\
\text { Ben } \\
\text { efits }\end{array}$ & $\begin{array}{c}\text { Futur } \\
\text { e } \\
\text { Need } \\
s \\
\end{array}$ & 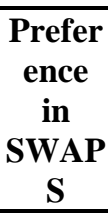 \\
\hline Risk & 1 & & & & & \\
\hline Return & $\begin{array}{r}- \\
0.5 \\
41\end{array}$ & 1 & & & & \\
\hline Safety & $\begin{array}{r}0.0 \\
94\end{array}$ & $\begin{array}{r}- \\
0.172\end{array}$ & 1 & & & \\
\hline $\begin{array}{l}\text { Tax } \\
\text { Benefits }\end{array}$ & $\begin{array}{r}0.0 \\
84\end{array}$ & $0.162^{-}$ & $\begin{array}{r}- \\
0.25 \\
1 \\
\end{array}$ & 1 & & \\
\hline $\begin{array}{l}\text { Future } \\
\text { Needs }\end{array}$ & $\begin{array}{r}- \\
0.1 \\
98 \\
\end{array}$ & 0.115 & $\begin{array}{r}0.34 \\
1\end{array}$ & $\begin{array}{r}- \\
0.01 \\
3\end{array}$ & 1 & \\
\hline $\begin{array}{l}\text { Preferenc } \\
\text { e } \\
\text { SWAPS }\end{array}$ & $\begin{array}{r}0.1 \\
32\end{array}$ & $\begin{array}{r}- \\
0.056\end{array}$ & $\begin{array}{r}- \\
0.03 \\
6 \\
\end{array}$ & $\begin{array}{r}- \\
0.03 \\
8 \\
\end{array}$ & 0.237 & 1 \\
\hline
\end{tabular}

The above table 4.3 shows correlation matrix of all the variables. From the analysis it concludes variables future needs \& returns are correlated highly among the variables. The correlate value is 0.115 ; the second higher correlate value is 0.094 , Safety and Risk. The next correlation ship variables Tax benefits and Risk. The other variables correlated negatively. In SWAPS market Investment preferences variables Future Needs \& Risk are highly correlated with values of $0.237 \& 0.132$.
Table: 4.4 Covariance of Investors Preference reasons in Share Market Investment Avenue:

\begin{tabular}{|c|c|c|c|c|c|c|}
\hline $\begin{array}{r}\text { COV } \\
\text { ARIAN } \\
\text { CES } \\
\end{array}$ & & & $\begin{array}{r}\text { Est } \\
\text { imate }\end{array}$ & $\begin{array}{l}\text { S. } \\
\text { E. }\end{array}$ & $\begin{array}{l}\text { C. } \\
\text { R. }\end{array}$ & $\mathrm{P}$ \\
\hline $\begin{array}{l}\text { Tax } \\
\text { Benefits }\end{array}$ & $<-->$ & $\begin{array}{l}\text { Future } \\
\text { Needs }\end{array}$ & 0.005 & 0.024 & 0.199 & 0.842 \\
\hline Safety & $<-->$ & $\begin{array}{c}\text { Tax } \\
\text { Benefits }\end{array}$ & $\begin{array}{r}- \\
0.205\end{array}$ & 0.057 & 3.601 & $* * *$ \\
\hline Return & $<-->$ & Safety & 0.089 & 0.036 & -2.51 & 0.012 \\
\hline Risk & $<-->$ & Return & 0.139 & 0.02 & 7.039 & $* * *$ \\
\hline Safety & $<-->$ & $\begin{array}{l}\text { Future } \\
\text { Needs }\end{array}$ & 0.161 & 0.034 & $\begin{array}{r}- \\
4.779\end{array}$ & $* * *$ \\
\hline Risk & $<-->$ & Safety & 0.05 & 0.036 & 1.388 & 0.165 \\
\hline Risk & $<-->$ & $\begin{array}{c}\text { Tax } \\
\text { Benefits }\end{array}$ & 0.034 & 0.027 & 1.238 & 0.216 \\
\hline Return & $<-->$ & $\begin{array}{l}\text { Future } \\
\text { Needs }\end{array}$ & 0.026 & 0.015 & 1.693 & 0.09 \\
\hline Risk & $<-->$ & $\begin{array}{l}\text { Future } \\
\text { Needs }\end{array}$ & $\begin{array}{r}- \\
0.046\end{array}$ & 0.016 & $\begin{array}{r}- \\
2.876\end{array}$ & 0.004 \\
\hline Return & $<-->$ & $\begin{array}{c}\text { Tax } \\
\text { Benefits }\end{array}$ & 0.063 & 0.027 & 2.367 & 0.018 \\
\hline
\end{tabular}

The above table 4.4 interprets Covariance relationship of investors preference reason in SWAPS Investment.

There is no significant relationship among the all variables, the estimated values are negative and $\mathrm{P}-$ Values are greater than 0.05 .

\section{FINDINGS AND SUGGESTIONS}

\section{1: Findings of the Study}

1. The preference reason in the Forward Contract Investment is Return.

2. The preference reason in the Future Contract Investment is Risk and Safety.

3. The preference reason in the Investment in the Options market is Future Needs.

4. The preference reason in the Investment in the Swaps market is Future Needs.

\section{2: Suggestions for Investors:}

The results of the study reflect the Investors Investment preferences reasons in the Derivative investment avenues market.

In accordance with the research findings, the following suggestions are offered...

A. For the Regulating Body - To formulate policies for regulating and controlling the operations of derivatives market in India.

1. The regulating bodies have to take suitable measures to propagate the information regarding derivative products and its features, operations, merits and demerits of derivative investment in India

2. Derivative Investors have mainly preferred reason is to invest in futures and SWAPS market is future needs than other derivative products. Because of lack of awareness other derivative products have not preferred by the investors. Therefore, the regulatory body should take required instigation to popularize the available Indian derivative products to the derivative investors. 
3. The regulating authority should consider investors' gender, age, marital status, educational qualification, and occupation, while creating awareness on derivative products and derivative investment as these five socio economic variables have significant impact on investors' perception towards derivative market.

4. Section 305 of the FDIC Improvement Act requires increased disclosure of derivative exposures, and Section 308 requires banks to establish standards to evaluate their exposure to weak institutions, including those arising from derivative products

B. For Corporate Sectors - To suggest appropriate instruments

1. Corporate sectors should provide adequate information about the derivative products, market condition, risk-return and opportunities for making right decisions to the investors in derivative instruments.

2. The corporate sectors should consider the socio economic variables of investors such as age, gender, marital status, educational qualifications, and occupation have significant impact on investors' investment decision on derivative market.

C. For the Derivative Investors - To make right decision at right time towards derivative products.

1. Derivative investors should perceive the government policies and market regulation, market trend, market reforms, obviously of the respondents have had high level perception on Indian derivatives market. Increased perception on derivative Investment can help the investors to make sensible investment decision at the right time.

2. Derivative investors ought to consider the motivating factors i.e., factors influencing derivative investment in India such as expectations, comfort ability, low brokerage, worldwide demand for derivative instruments, less volatility, investors' participation, earnings, index \& sensex, profitability, demand of scrips, economic condition of the country, government policies, market efficiency and trends in foreign market while investing in derivative instruments.

\section{CONCLUSION}

The study determines that the investors preference reasons in the derivative investment is different in different investment avenues. The investors preference reason in derivative investments is depends upon the investment objective such as Risk, Return, Safety and liquidity of the investment. Most of the investors enter into the Forward Contract investments is Return, Future Contract investments is Risk and Safety, Option Contract Investment is Future Needs and Investments in Swaps is Future Needs.

\section{SCOPE FOR FUTURE RESEARCH}

The following topics have been suggested for future researchers to undertake their studies with a view to gain intensive and extensive information on derivative market in India.

1. Opportunities and Challenges of Investing in Funds in Indian Future and Options - A Comparative Study.

2. Analysis of Derivative Products in Indian Derivatives Market.
3. Impact of Policy Initiatives on Investors Investment Decisions in Indian Derivatives Market.

4. Investors Perception towards Risk in Derivatives Market in India.

\section{REFERENCES}

1. Szyszka Adam, (2008). Behavioural Anatomy of the Financial Crisis. Journal of CENTRUM Cathedra, Vol. 3 (2).

2. Fauver and Naranjo, (2010). Derivative Usage and Firm Value: The Influence of Agency Costs and Monitoring Problems. Journal of Corporate Finance 16, 719-735.

3. Hoffmann et al (2011). Guide to Financial Independence. Crown Publishers Inc. 201, New York 100022, 2000.

4. Hoffmann and Post (2012). What Makes Investors Optimistic? What Makes Them Afraid? (Working Paper). Maastricht University and Netspar, The Netherlands, pp. 1-40.

5. Allayannis, Lel and Miller (2012). The Use of Foreign Currency Derivatives and Firm Market Value. Review of Financial Studies 14, 243-276.

6. Dr. Y. Nagaraju, S. R. (2014). A Study on Investors' Perception Towards Derivative Instruments and Markets. International Journal of Research In Commerce, Economics \& Management , 4 (7).

7. Tripathi, G. (2014). An Empirical Investigation of Investors Perception Towards Derivative Trading. Global Journal of Finance and Management, 6 (2), 99-104.

8. Divya Verma Gakhar (2012). Indian Derivatives Market: A Study of Impact on Volatility and Investor Perception. doi: 10.18178/ijssh.2016.6.12.772

9. 9.Gopal Krishna U M (2019) Investors Perception towards Investment Avenues. International Journal of Recent Technology and Engineering 8(2), 1401-1411

10. Gopal Krishna U M (2019) Perception of Investors towards risk in various Investment Avenues. International Journal of Recen Technology and Engineering 8(2),26751-2681

11. Bhalla V.K.(2013). Investment Management -Security Analysis and Portfolio Management, 14th edition, S.Chand\& Co Ltd., New Delhi 110055 .

\section{AUTHORS PROFILE}

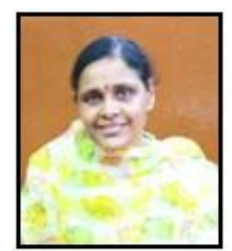

Dr. N RENUKA, Professor in Avanthi PG College, Dilsukhnagar, Hyderabad, Telangana State (500036). Experience: Overall 15+ years of Teaching and research experience. Publications: International Journals :36 10 National Journals: 07; Conferences :International : 07 National : 15, Books/Chapters in books: 02; Research Areas : Financial Analysis, Investment Analysis \& Portfolio Management, Stream of Lecturing :Financial Management \& Financial Accounting, Operation Research, International Finance, Statistics for Management, Security Analysis \& Portfolio Management, International Finance, Entrepreneur Development \&HRP. 